\title{
UNIVERSITYOF
}

FORWARD

THINKING

WESTMINSTER用

WestminsterResearch

http://www.westminster.ac.uk/westminsterresearch

\section{Linking the ecosystem service approach to social preferences and needs in integrated coastal land use management - a planning approach}

Karrasch, L., Klenke, T. and Woltjer, J.

NOTICE: this is the authors' version of a work that was accepted for publication in Land Use Policy. Changes resulting from the publishing process, such as peer review, editing, corrections, structural formatting, and other quality control mechanisms may not be reflected in this document. Changes may have been made to this work since it was submitted for publication. A definitive version was subsequently published in Land Use Policy, 38, 522-532.

Land Use Policy is available online at:

https://dx.doi.org/10.1016/..landusepol.2013.12.010

(C) 2014. This manuscript version is made available under the CC-BY-NC-ND 4.0 license http://creativecommons.org/licenses/by-nc-nd/4.0/

The WestminsterResearch online digital archive at the University of Westminster aims to make the research output of the University available to a wider audience. Copyright and Moral Rights remain with the authors and/or copyright owners.

Whilst further distribution of specific materials from within this archive is forbidden, you may freely distribute the URL of WestminsterResearch: ((http://westminsterresearch.wmin.ac.uk/)).

In case of abuse or copyright appearing without permission e-mail repository@westminster.ac.uk 
Provided for non-commercial research and education use. Not for reproduction, distribution or commercial use.

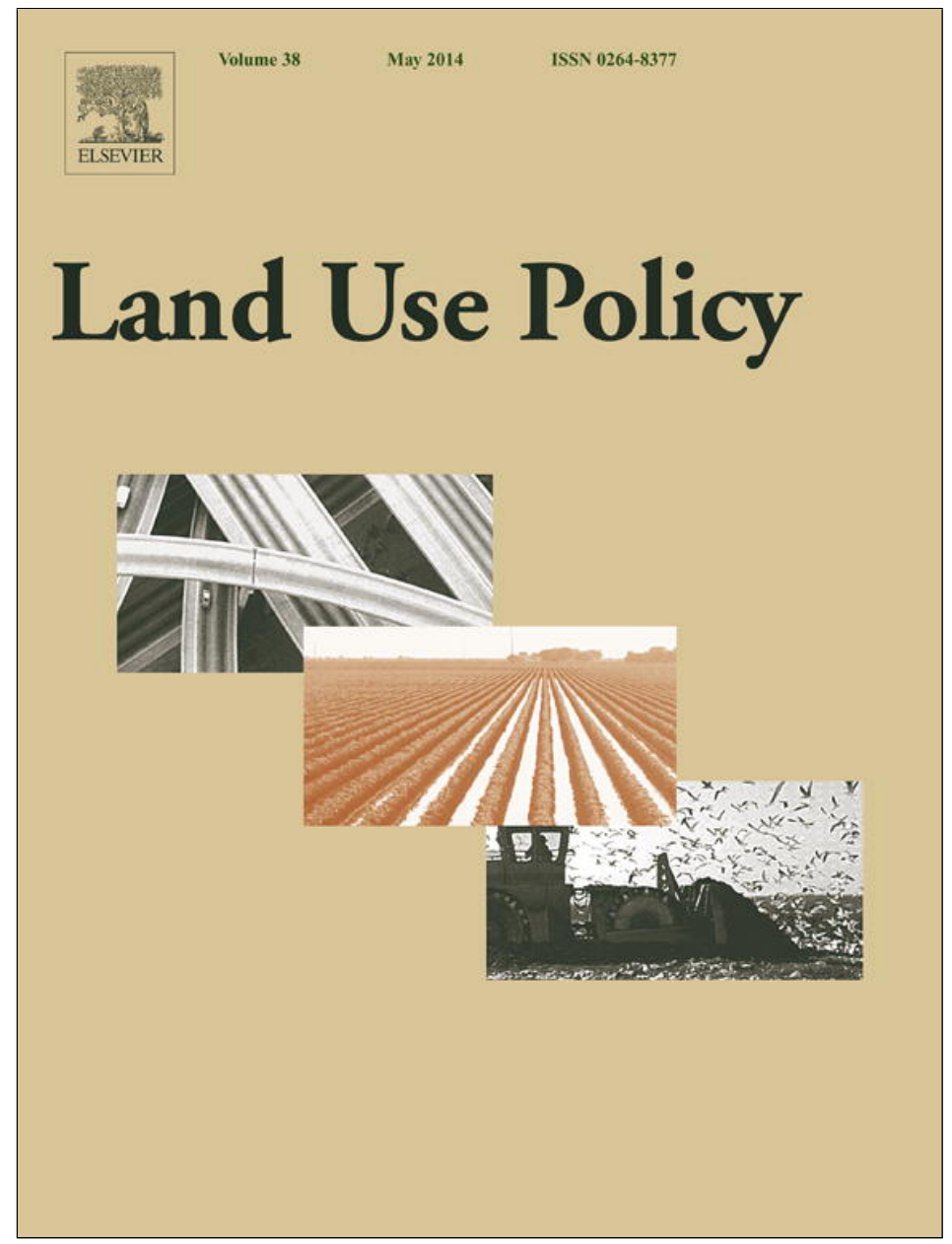

This article appeared in a journal published by Elsevier. The attached copy is furnished to the author for internal non-commercial research and education use, including for instruction at the authors institution and sharing with colleagues.

Other uses, including reproduction and distribution, or selling or licensing copies, or posting to personal, institutional or third party websites are prohibited.

In most cases authors are permitted to post their version of the article (e.g. in Word or Tex form) to their personal website or institutional repository. Authors requiring further information regarding Elsevier's archiving and manuscript policies are encouraged to visit:

http://www.elsevier.com/authorsrights 


\title{
Linking the ecosystem services approach to social preferences and needs in integrated coastal land use management - A planning approach
}

\author{
Leena Karrasch $^{\mathrm{a}, *, 1}$, Thomas Klenke ${ }^{\mathrm{a}, 1}$, Johan Woltjer ${ }^{\mathrm{b}, 2}$ \\ a COAST - Centre for Environmental and Sustainability Research, University of Oldenburg, P.O. Box 2503, 26111 Oldenburg, Germany \\ ${ }^{\mathrm{b}}$ Faculty of Spatial Sciences, University of Groningen, Landleven 1, 9747 AD Groningen, The Netherlands
}

\section{A R T I C L E I N F O}

\section{Article history:}

Received 20 December 2012

Received in revised form 4 November 2013

Accepted 16 December 2013

\section{Keywords:}

North Sea

Climate adaptation

Participation

Ecosystem services

Social impact

\begin{abstract}
A B S T R A C T
Coastal zones with their natural and societal sub-systems are exposed to rapid changes and pressures on resources. Scarcity of space and impacts of climate change are prominent drivers of land use and adaptation management today. Necessary modifications to present land use management strategies and schemes influence both the structures of coastal communities and the ecosystems involved. Approaches to identify the impacts and account for (i) the linkages between social preferences and needs and (ii) ecosystem services in coastal zones have been largely absent. The presented method focuses on improving the inclusion of ecosystem services in planning processes and clarifies the linkages with social impacts. In this study, fourteen stakeholders in decision-making on land use planning in the region of Krummhörn (northwestern Germany, southern North Sea coastal region) conducted a regional participative and informal process for local planning capable to adapt to climate driven changes. It is argued that scientific and practical implications of this integrated assessment focus on multi-functional options and contribute to more sustainable practices in future land use planning. The method operationalizes the ecosystem service approach and social impact analysis and demonstrates that social demands and provision of ecosystem services are inherently connected.
\end{abstract}

(c) 2014 Elsevier Ltd. All rights reserved.

\section{Introduction}

The coastal lowlands and estuaries of northwestern Europe are constantly changing and the population is dealing with increasing competition for space and resources. Today, the increasing use of resources is leading to growing pressure and conflict between the different forms of land use and ecosystems (e.g. European Union, 2012). In relation to southern coastal regions of the North Sea, the natural and societal systems must also deal with the consequences and effects of climate change (Nicholls et al., 2007). For the coast of the Wadden Sea, Katsman et al. (2011) estimate a regional sea level rise of $0.40-1.05 \mathrm{~m}$ by 2100 . Additionally, the North Sea coastal areas are also exposed to significant and increasing storm events (Beniston et al., 2007; Grabemann and Weisse, 2008; Nicholls et al., 2007; Woth et al., 2005) and shifts in precipitation's scale and time (Beniston et al., 2007; Jacob et al., 2008; Spekat et al., 2007).

\footnotetext{
* Corresponding author. Tel.: +49 0441798 4328; fax: +49 04417985099.

E-mail addresses: leena.karrasch@uni-oldenburg.de, leenakarrasch@yahoo.de, coast@uni-oldenburg.de (L. Karrasch), j.woltjer@rug.nl (J. Woltjer).

1 Tel.: +490441798 4799; fax: +4904417985099.

2 Tel.: +31503633876.
}

Necessary changes in current land use management may lead to both beneficial and adverse effects on human well-being and the ecosystem health of a region. Therefore, long-term anticipatory and spatially explicit courses of action are required. There is an obvious need for adaptive planning strategies which will lead to more sustainable development and promote human wellbeing (e.g. Ahlhorn, 2009; Bormann et al., 2012). The objective of this paper, therefore, is to develop an applicable methodology for sustainable development in land management, combining the ecosystem services approach and social impact assessment.

In order to find sustainable solutions, the ecosystem services approach has become prominent in the promotion of sustainable development and ecosystem-based land use management (Fisher et al., 2009; de Groot et al., 2010). Ecosystem services, meaning the goods and services people obtain from ecosystems, play an important role in sustaining and fulfilling human life. While the ecosystem services approach takes into account effects on socio-economic factors and contributes to human well-being by focusing on the supply of ecosystem services (MA, 2003), social impact assessment identifies, analyses and evaluates the social impact of projects on people and ecological structures, and focuses on the process of managing social issues related to development (Esteves et al., 2012; Vanclay, 2003a; Vanclay, 
2012). Social impacts include 'the consequences to human populations of any public or private action' affecting human well-being (Interorganizational Committee on Guidelines and Principles for Social Impact Assessment, 1995, p. 11). Although ecosystems provide distinct environmental benefits to people and affect human well-being (MA, 2003; UK National Ecosystem Assessment, 2011), the linkages between the natural and the social spheres and the mutual feedback mechanisms are not always well defined. There has been a general lack of understanding on the relationship between ecosystem services and the social impacts of an intervention (Burdge, 2003; Vanclay, 2003b; Wallace, 2007) and a strong awareness in coastal management practice over the last decade that decision-makers and scientists need to jointly address the challenges of an integrative and interdisciplinary management approach (Fish et al., 2011; Österblom et al., 2010; Polasky et al., 2011). Such an approach would include consideration of the interdependencies arising from the complex interactions between nature and society (Carpenter et al., 2009; Slootweg et al., 2001; Vanclay, 2012).

This paper argues that addressing these linkages, interdependencies and feedback mechanisms is important, particularly for regional planning practice, as planners typically deal with balancing different activities and interests in relation to land use. A potentially promising way of addressing these linkages is the "social impact assessment' approach (see also Schirmer, 2011; Vanclay, 2012).

Overall, the paper presents a framework and guideline for linking the ecosystem services approach with social preferences and needs. A guideline such as this could be used to assist planners and researchers establish a more integrated, possibly participatory, policy development process, particularly in relation to regional development.

A key idea behind the guideline is that development and management processes have to take into account the mutual interdependencies between environmental and societal changes caused by planning-related interventions. Generally, a separation of ecosystem services and the related social impact on communities is likely to generate problems and incomplete impact assessments (Slootweg et al., 2001; Chan et al., 2012; de Groot et al., 2010; Nahlik et al., 2012). To overcome this problem, this paper reports on an effort to develop guidelines that allow for a consideration of social and environmental issues in an integrated manner.

The paper argues that our guideline may support decisionmaking in this case, as it has the potential to reduce complexity and can be employed to encourage stakeholder participation. Another implication of the guideline may be its ability to produce innovative courses of action, leading to more sustainable and multi-functional land management. Finally, the integrated approach developed here is also essentially transdisciplinary as it involves the natural and social sciences, and negotiates the separation between humans and the environment.

The illustrative case employed involved regional governance processes on regional climate adaptation strategies in the area of Krummhörn in northwestern Germany (Fig. 1).

The increasing scarcity of resources and expected impact of accelerated climate change constitute major problems for land use management in the case study region (see also Ahlhorn, 2009; Bormann et al., 2012). Change in land use also affects the population and thus has a social impact, while the ability of the ecosystem to provide services might also be affected (MA, 2003; Schirmer, 2011; Vanclay, 2012). This paper considers a variety of ecosystem services and social impacts, combined with science and stakeholder-driven actions that concentrate on sustainable development and human well-being.

\section{Assessment methodology}

The following section will explain how the concept of ecosystem services can be anchored in local decision-making and planning processes to meet the changing conditions and need for action, as well as to promote sustainable development.

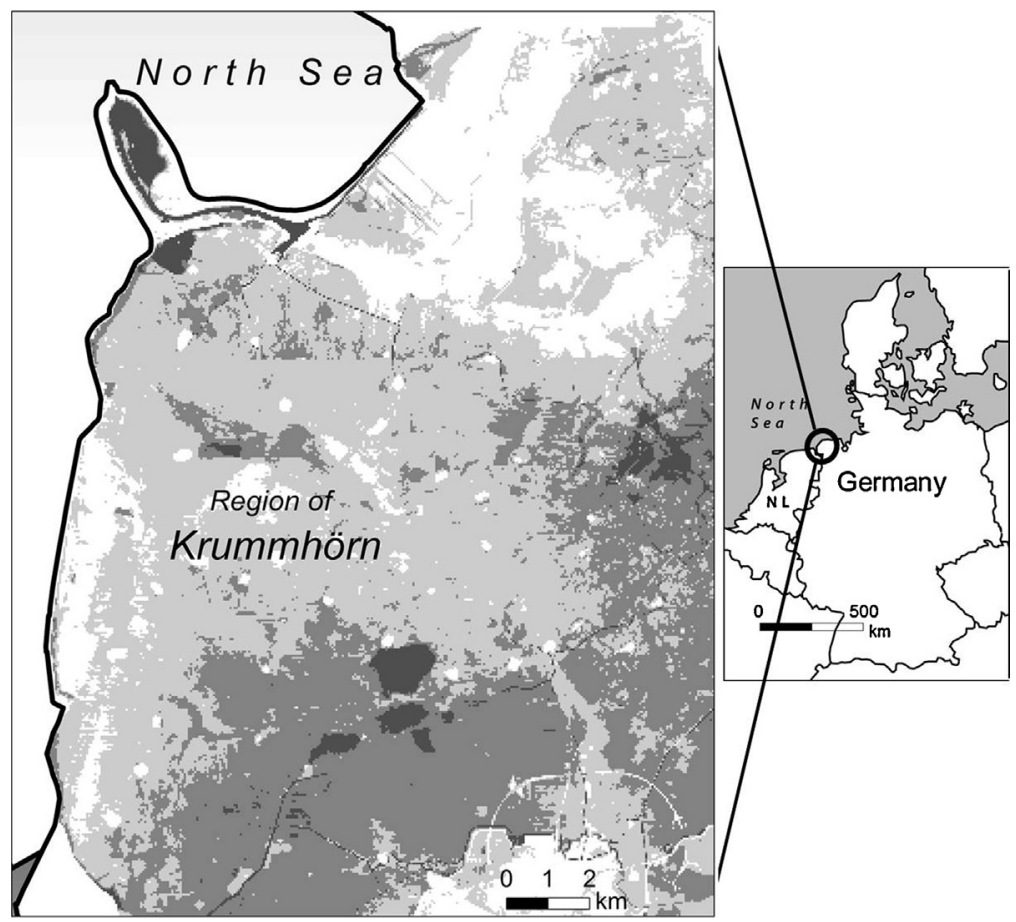

Fig. 1. Topography of the pilot region of Krummhörn, northwestern Germany. Most parts of the community $\left(159 \mathrm{~km}^{2}, 12,600\right.$ inhabitants $)$ are located within low-lying marsh. Due to the tidal influence of the North Sea, it is almost impossible to maintain unprotected settlements within the low-lying areas. Today, about one-third of the total area is below sea level. White $=>1 \mathrm{~m}$ asl, light grey $=0-1 \mathrm{~m}$ asl, grey $=0-1 \mathrm{~m}$ asl, dark grey $=<-1 \mathrm{~m}$ asl. Source: ( $)$ LGLN, 2012 . 


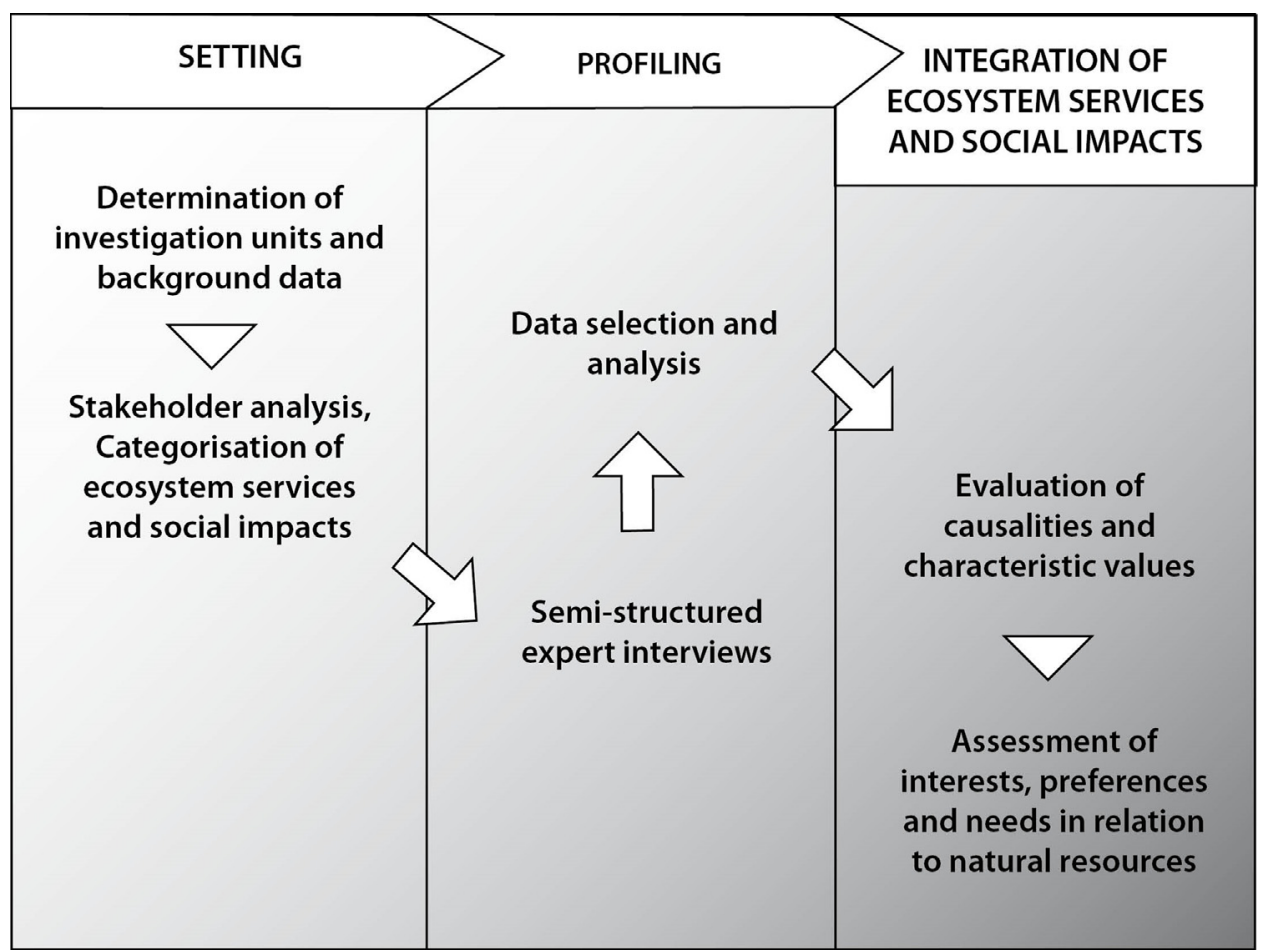

Fig. 2. Stepwise approach to participatory adaptive land use planning management as developed and tested in this study. The process schema shows the three main stages in the approach (setting, profiling and integration of ecosystem services and social impacts), including six action-oriented steps. The grey colour indicates the intensity of stakeholder participation (light grey $=$ low, dark grey $=$ high).

An overview of the methodology applied in this paper is provided in Fig. 2, which focuses on the so-called process schema.

The process schema presented in Fig. 2 shows the three main stages of the approach developed. Within the process shown, the course of action moves from science-driven actions, meaning the use of theoretical background data and literature, towards stakeholder-driven actions. Stakeholder involvement and engagement is an important part of the methodology because it implies the use of local, traditional and expert knowledge while simultaneously including the stakeholder-based identification of ecosystem services, key issues, possible impacts, synergies and trade-offs in decision-making on future land use management. Sustainable regional development is essentially determined by interaction between the relevant stakeholders (e.g. agriculture, nature conservation, tourism, water management and policy). A key analytical aspect, therefore, in understanding the linkages between ecosystem services and the social impact implies an understanding of the position of each of the stakeholders. The analysis, therefore, sets out to investigate the knowledge, experiences and needs of each stakeholder in relation to achieving better development outcomes for the region affected (see also Salter et al., 2010). The ecosystem services approach is used as a strategy to integrate local ecosystem services - ecosystem-based material and non-material resources as the source of supply from which benefits are produced - into decisionmaking (MA 2003). Similarly a social impact assessment promotes the inclusion of the social impacts of an intervention on the community in any decision-making process (Vanclay, 2003a; Vanclay and Esteves, 2011). The basic idea of the methodology, therefore, is that the ecosystem services describe the supply side, while the social impact concerns the stakeholders' requirements and reflects the demands of the stakeholders with regard to changing environmental conditions. The consideration of both parameters should thus promote the sustainable development of the region affected.

\section{Setting}

The first step was to define the setting and scope of the spatial planning activity (the intervention). This step involved a review of policy documents and related background material from the region. In a second step, the theoretical identification of the ecosystem services and social impacts categories reduced the complex terminology of the natural and climate sciences into understandable units, with these categories determining the indicators which would be used as guidelines for extracting information in the interviews. Numerous ways of categorizing ecosystem services can be found in the literature (Constanza et al., 1997; de Groot et al., 2002; UK National Ecosystem Assessment, 2011). Following the MA (2003), this paper classified ecosystem services along functional lines and focused on four categories: provisioning, regulating, cultural and supporting services.

Human well-being not only depends on ecosystem services but also on the perceptions, interests and needs of the wider community. Therefore, social impact assessment is considered to be an appropriate concept to systematically examine and analyze statements about how people feel and might respond to changes in their region and how changes might affect their lives (see also Burdge, 1999, 2003; Vanclay, 2003a; Vanclay and Esteves, 2011). Based on Vanclay (2002), the social impacts were divided into six different categories: personal, developmental, economic, climate change, cultural and ecological impacts.

Another aspect of the setting is stakeholder engagement. In this methodology, efforts were thus made to include all of the relevant stakeholders and to actively involve their experiences and knowledge in relation to land management (e.g. Flannery and Cinnéide, 2011; Neef and Neubert, 2001) in the research process. The criteria for selecting the stakeholders related to their individual background and knowledge about regional land use and management, 
Table 1

List of local and regional stakeholders participating in this study and the sectors they represent.

\begin{tabular}{ll}
\hline Sector & Institution \\
\hline Water & Water board Emden \\
management & Water board Emden (engineer) \\
& Dike board Krummhörn \\
& National park authority of Lower \\
Nature & Saxony \\
conservation & Biosphere Reserve authority, Lower \\
& Saxony \\
& NABU Woldenhof (Nature and \\
& biodiversity conservation union, NGO) \\
& Farmers Association East Frisia \\
& Farmer \\
Agriculture & Chamber of Agriculture Lower Saxony \\
& Community of Krummhörn \\
Regional and & County of Aurich \\
local & State estate agency, Norden \\
bovernmental & Representative of the community of \\
& Krummhörn \\
Tourism & Tourism Association, East Frisia \\
\hline
\end{tabular}

as well as ensuring a balance of different sectors. Table 1 presents the different stakeholders and their specific fields of interest.

\section{Profiling}

Following the process schema (Fig. 2, profiling), a stakeholder dialogue in the form of semi-structured interviews was used to identify important social and environmental issues in order to improve decision-making, data selection and the analysis. Therefore, semi-structured expert interviews were used as a suitable tool to discuss social and ecological concerns and contribute to the understanding of complex relationships (see also Bogner et al., 2009; Flick, 2006). The advantages of semi-structured expert interviews include the flexibility of the interviewer to adapt to the stakeholder, a continuous communicative interaction process between expert and interviewer, the ability to correlate various statements, the critical questioning of competing alternatives and the building of mutual trust (Flick, 2006).

To structure the interviews and address issues of crucial interest, a questionnaire was used. This questionnaire addressed central problem definitions, included open and hypothesis-directed questions and encouraged open dialogue (e.g. Bogner et al., 2009; Flick, 2006). The semi-structured interviews were conducted with a sample of fourteen experts who represented crucial sectors of the case study region, namely, water management, agriculture, nature conservation, policy and tourism (Table 1). The questionnaire included questions about the personal background of the experts and solicited their opinions concerning sustainable land management and changes in current land use within the case study region.

The second step of the profiling process incorporated the selection, editing and analysis of data from both the literature and the interviews. The semi-structures interviews were recorded and transcribed, providing a qualitative data set for identifying crucial information on ecosystem services and social impacts. A structured qualitative content analysis was performed on the transcripts. The theoretically developed categories of ecosystem services and social impacts were used as guidelines for screening the material and interpreting and extracting the information. Information about the environmental and social contexts and the latest opinions on these were gathered.

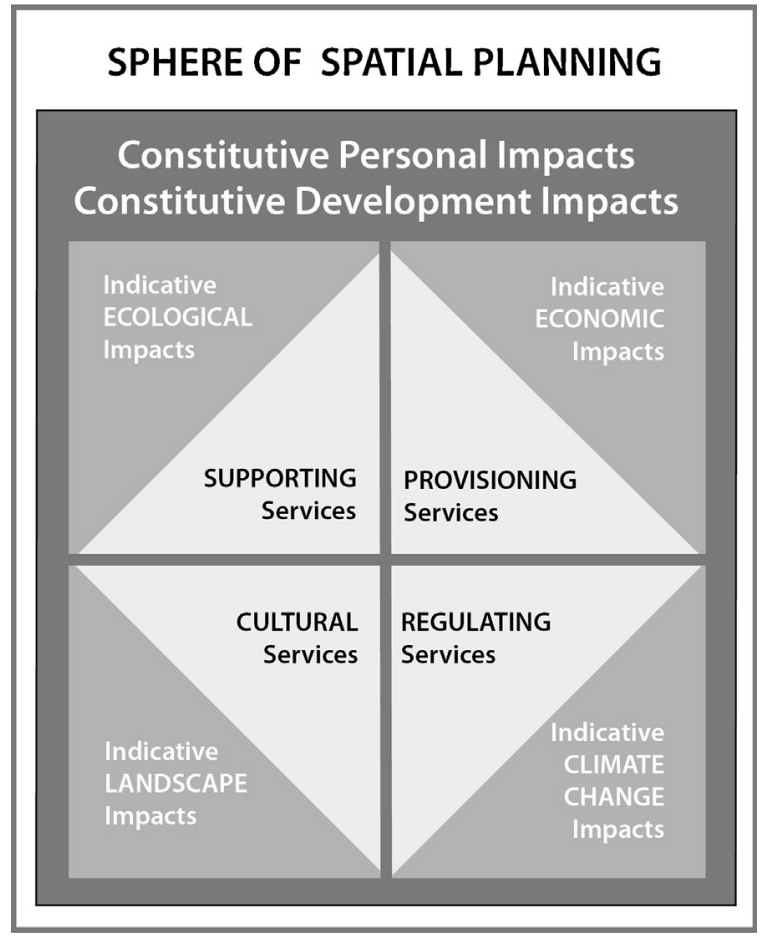

Fig. 3. Integration of ecosystem services and social impacts in the sphere of spatial planning. Constitutive impacts influence all categories of ecosystem services, whereas indicative impacts directly influence one category of services.

\section{Integration of ecosystem services and social impacts}

The interviews were used to identify the participants' perspectives on the ecosystem services within the case study region and the social impacts that the experts considered to be relevant and caused by interventions in the environment. In quantifying the results of the interviews, these services and impacts were used as indicators: (i) to promote the process of their integration and (ii) to analyze causalities and characteristics. Fig. 3 summarizes the relationships of ecosystem services and social impacts by compressing the stakeholder's suggestions into the previously developed categories. The result is an assessment of interests, preferences and needs in relation to natural resources, leading to the overall goal the development of a sustainable land use strategy ready for implementation.

\section{Results}

The results from the conducted process schema suggest an aggregation of ecosystem services, indicative social impacts and constitutive social impacts (Fig. 3 ) as keys to integrating ecosystem services into spatial planning. This section provides examples on how ecosystem services are interlinked with social impacts, and which factors may be crucial for the development of sustainable land use management strategies. The process of analysing the data gathered in the semi-structured expert interviews made clear that social impacts are interlinked with the ecosystem services approach, particularly when changes in land use are taking place.

Stakeholder participation in our study included the consultation (through interviews and dialogues) with experts representing important sectors of society (Table 1 ). In this study, the ecosystem services and social impacts were spatially defined by the stakeholders and the area in which the changes and activities were occurring. Definitions of services and indicators were adjusted and amended according to the stakeholders' statements (see Tables 2 and 3 ). The research process demonstrated why it is 
Table 2

List of social impacts assessed in the coastal region of Krummhörn. Based on Vanclay (2002), the impacts are divided into two categories of constitutive impacts (personal and development impacts) and four categories of indicative social impacts (economic, climate change, landscape and ecological impacts). The criteria are defined according to Vanclay (2002) and by the stakeholders. The right side of the table illustrates the sectoral distribution of the stakeholders' statements. The colours of the boxes indicate the percentage of expression of opinions concerning the criteria. $\mathrm{W}=$ water management, $\mathrm{N}=$ nature conservation, $\mathrm{A}=$ agriculture, $\mathrm{P}=$ policy, $\mathrm{T}=$ tourism. Grey $=>66 \%$, light grey $=33-66 \%$, white $=<33 \%$.

\begin{tabular}{|c|c|c|c|c|c|c|c|}
\hline Category & $\begin{array}{l}\text { Social impact } \\
\text { (Indicator) }\end{array}$ & $\begin{array}{l}\text { Criteria provided by the local stakeholders and } \\
\text { according to Vanclay (2002) }\end{array}$ & $\mathbf{W}$ & $\mathbf{N}$ & A & $\mathbf{P}$ & $\mathbf{T}$ \\
\hline \multirow{5}{*}{$\begin{array}{l}\text { Constitutive } \\
\text { Personal } \\
\text { Impacts }\end{array}$} & Attachment to place & $\begin{array}{l}\text { Sense of place, regional belonging, how people feel } \\
\text { about their surroundings, community cohesion. }\end{array}$ & & & & & \\
\hline & $\begin{array}{l}\text { Obligation to ancestors } \\
\text { and traditions }\end{array}$ & $\begin{array}{l}\text { Nostalgic feelings, change in culture, local language, } \\
\text { beliefs. }\end{array}$ & & & & & \\
\hline & $\begin{array}{l}\text { Participation in decision- } \\
\text { making }\end{array}$ & $\begin{array}{l}\text { Participation and integration in decision-making } \\
\text { processes, transparency. }\end{array}$ & & & & & \\
\hline & Positive outcomes & $\begin{array}{l}\text { Interventions and new courses of action should lead to } \\
\text { positive outcomes for all affected parties. }\end{array}$ & & & & & \\
\hline & Trust in Policy & $\begin{array}{l}\text { Integrity of decision-makers and policy, experiences with } \\
\text { change. }\end{array}$ & & & & & \\
\hline \multirow{5}{*}{$\begin{array}{l}\text { Constitutive } \\
\text { Development } \\
\text { Impacts }\end{array}$} & $\begin{array}{l}\text { Need for adaption } \\
\text { measures }\end{array}$ & $\begin{array}{l}\text { Aspirations for the future, change in thinking concerning } \\
\text { climate change impacts and current land use } \\
\text { management. }\end{array}$ & & & & & \\
\hline & $\begin{array}{l}\text { Positioning of new land } \\
\text { use strategies }\end{array}$ & $\begin{array}{l}\text { Not in my backyard mentality, development of regional } \\
\text { schemes, presence of planning activities. }\end{array}$ & & & & & \\
\hline & Competing land uses & $\begin{array}{l}\text { Decrease of competing land use by consensus finding } \\
\text { and combinations between diverse land uses, multi- } \\
\text { functionality. }\end{array}$ & & & & & \\
\hline & $\begin{array}{l}\text { Compliance with } \\
\text { property rights and } \\
\text { values }\end{array}$ & $\begin{array}{l}\text { Avoidance of fear of expropriation and losing land and } \\
\text { perspectives, concerns of displacements. }\end{array}$ & & & & & \\
\hline & $\begin{array}{l}\text { Need for a long-time } \\
\text { view }\end{array}$ & $\begin{array}{l}\text { New adaptive land use management strategies need a } \\
\text { long-time horizon. }\end{array}$ & & & & & \\
\hline \multirow{4}{*}{$\begin{array}{l}\text { Indicative } \\
\text { Economic } \\
\text { Impacts }\end{array}$} & Security of income & Impact on the security of income and employment. & & & & & \\
\hline & $\begin{array}{l}\text { Economic prosperity and } \\
\text { resilience of the region }\end{array}$ & $\begin{array}{l}\text { Land use elements that promote well-being and } \\
\text { stimulate economy, access to resources. }\end{array}$ & & & & & \\
\hline & $\begin{array}{l}\text { Maintenance of } \\
\text { agricultural and } \\
\text { grassland }\end{array}$ & $\begin{array}{l}\text { Maintenance of agricultural and grassland to ensure all } \\
\text { kinds of related demands. }\end{array}$ & & & & & \\
\hline & $\begin{array}{l}\text { Security of food and } \\
\text { drinking water supply }\end{array}$ & $\begin{array}{l}\text { Securing food and freshwater supply, access to } \\
\text { resources. }\end{array}$ & & & & & \\
\hline \multirow{2}{*}{$\begin{array}{l}\text { Indicative } \\
\text { Climate } \\
\text { Change } \\
\text { Impacts }\end{array}$} & $\begin{array}{l}\text { Combat negative } \\
\text { influences of increasing } \\
\text { sea level, inland water } \\
\text { levels, droughts, dike } \\
\text { overtopping }\end{array}$ & $\begin{array}{l}\text { Due to changes in land use, negative impacts of climate } \\
\text { change induced alterations might be reduced and the } \\
\text { feeling of safety might be strengthened. }\end{array}$ & & & & & \\
\hline & Perception of safety & $\begin{array}{l}\text { Changes which are leading to a decrease in the degree } \\
\text { of risks (technical und non-technical solutions), feelings } \\
\text { of hazard exposure, perception of personal safety. }\end{array}$ & & & & & \\
\hline \multirow{3}{*}{$\begin{array}{l}\text { Indicative } \\
\text { Landscape } \\
\text { Impacts }\end{array}$} & $\begin{array}{l}\text { Aesthetic quality, beauty } \\
\text { of the landscape }\end{array}$ & $\begin{array}{l}\text { Effects on visual impressions concerning the landscape } \\
\text { and how changes influence the well-being and sense of } \\
\text { place. Visual impacts, outlook, exposure to noise. }\end{array}$ & & & & & \\
\hline & Presence of tourists & $\begin{array}{l}\text { Impacts of tourists on daily life, disruption to daily living } \\
\text { practice. }\end{array}$ & & & & & \\
\hline & Cultural-historical values & $\begin{array}{l}\text { Significance of cultural-historical values like terp villages } \\
\text { and traditions. }\end{array}$ & & & & & \\
\hline \multirow{2}{*}{$\begin{array}{l}\text { Indicative } \\
\text { Ecological } \\
\text { Impacts }\end{array}$} & Beauty of nature & Influence of changes on the beauty of nature. & & & & & \\
\hline & $\begin{array}{l}\text { Organic management, } \\
\text { sustainable use of } \\
\text { resources }\end{array}$ & $\begin{array}{l}\text { Effects of organic management (natural sound } \\
\text { production methods, inclusion of nature conservation } \\
\text { measures, sustainable land use). }\end{array}$ & & & & & \\
\hline
\end{tabular}

important to work with open categories and an inductive analysis as it encouraged the stakeholders to provide more background data and thus be more actively engaged in determining the research objectives.

Tables 2 and 3 provide an overview of the classification of social impacts and ecosystem services. Each category of social impacts and ecosystem services includes a set of indicators. In addition to the associated social impacts' and ecosystem services' criteria, both tables provide a sectoral distribution of the stakeholders' statements. The dark colour indicates a high percentage of expression of opinions concerning one criterion, whereas the white boxes indicate that there is no statement concerning the criteria.

\section{Integration of constitutive impacts in spatial planning}

The results suggest that consideration of constitutive social impacts (Table 2) is the basic requirement for a management process that takes stakeholders' relationships, concerns and prospects into account. These impacts refer to (i) constitutive personal impacts, addressing people's community identification 
Table 3

List of ecosystem services provided by the coastal ecosystem. The services (serving as indicators) are divided into: (i) provisioning, (ii) regulating, (iii) cultural and (iv) supporting services (MA, 2003). The criteria are defined according to MA (2003) and by the stakeholders. The right side of the table illustrates the sectoral distribution of the stakeholders' statements. The colours of the boxes indicate the percentage of expression of opinions concerning the criteria. $\mathrm{W}=$ water management, $\mathrm{N}=$ nature conservation, $\mathrm{A}=$ agriculture, $\mathrm{P}=$ policy, $\mathrm{T}=$ tourism. Grey $=>66 \%$, light grey $=33-66 \%$, white $=<33 \%$.

\begin{tabular}{|c|c|c|c|c|c|c|c|}
\hline Category & $\begin{array}{l}\text { Service } \\
\text { (Indicator) }\end{array}$ & $\begin{array}{l}\text { Criteria provided by the local stakeholders and } \\
\text { according to MA (2003) }\end{array}$ & $\mathbf{W}$ & $\mathbf{N}$ & A & $\mathbf{P}$ & $\mathbf{T}$ \\
\hline \multirow{4}{*}{$\begin{array}{l}\text { Provisioning } \\
\text { Services }\end{array}$} & Food production & $\begin{array}{l}\text { Plant and animal material which is used as food or for } \\
\text { the production of food. }\end{array}$ & & & & & \\
\hline & Forage production & Dairy farming and forage production. & & & & & \\
\hline & $\begin{array}{l}\text { Green energy } \\
\text { production }\end{array}$ & $\begin{array}{l}\text { Organic material serves as source of energy and is used } \\
\text { for energy generation. }\end{array}$ & & & & & \\
\hline & Fresh water & $\begin{array}{l}\text { Within dry periods the retained fresh water might be } \\
\text { used for irrigation measures and drinking water supply. }\end{array}$ & & & & & \\
\hline \multirow{5}{*}{$\begin{array}{l}\text { Regulating } \\
\text { Services }\end{array}$} & $\begin{array}{l}\text { Prevention of saltwater } \\
\text { intrusion }\end{array}$ & $\begin{array}{l}\text { Due to a freshwater polder the decrease of groundwater } \\
\text { level might be reduced and the hydrostatical pressure } \\
\text { increased. }\end{array}$ & & & & & \\
\hline & Wave attenuation & $\begin{array}{l}\text { Natural vegetation structures like salt marshes lead to } \\
\text { wave attenuation and promote coastal protection. }\end{array}$ & & & & & \\
\hline & $\begin{array}{l}\text { Hazard regulation by } \\
\text { water retention }\end{array}$ & $\begin{array}{l}\text { Retention areas for inland floods (extreme precipitation) } \\
\text { and saltwater (dike overtopping). }\end{array}$ & & & & & \\
\hline & Erosion control & $\begin{array}{l}\text { Avoidance of soil erosion due to water, wind or incorrect } \\
\text { management which leads to soil degradation or soil } \\
\text { damage. }\end{array}$ & & & & & \\
\hline & $\begin{array}{l}\text { Reduction of } \\
\text { greenhouse gases }\end{array}$ & Greenhouse gas reduction at global and local level. & & & & & \\
\hline \multirow{2}{*}{$\begin{array}{l}\text { Cultural } \\
\text { Services }\end{array}$} & $\begin{array}{l}\text { Community identification } \\
\text { and connection }\end{array}$ & $\begin{array}{l}\text { Regional belonging, the willingness to live there, } \\
\text { traditional relations and land use in terms of ecosystems } \\
\text { ('natural' landscape features). }\end{array}$ & & & & & \\
\hline & Recreation, tourism & $\begin{array}{l}\text { Attractive landscape and biotopes features strongly } \\
\text { linked with the ecosystems and landscape. }\end{array}$ & & & & & \\
\hline \multirow{2}{*}{$\begin{array}{l}\text { Supporting } \\
\text { Services }\end{array}$} & Biodiversity & $\begin{array}{l}\text { Diversity of species, genes and ecosystems. Habitats for } \\
\text { species. }\end{array}$ & & & & & \\
\hline & Quality of soil & $\begin{array}{l}\text { Soils are habitats and livelihoods for plants, animals and } \\
\text { human. They act as a groundwater filter, store nutrients } \\
\text { and accumulate organic matters. }\end{array}$ & & & & & \\
\hline
\end{tabular}

and connections as well as (ii) constitutive development impacts, addressing the expected effects of changes in land use and the perceptions and aspirations concerning new developments in general (Fig. 3 and Table 2). From the stakeholder point of view, these impacts are of fundamental concern to any course of action and determine access to the regional actors. To meet the constitutive social impacts within planning sessions, it is necessary, from the researchers' side, to communicate goals transparently and in understandable terms.

Regarding the constitutive personal impacts, attachment to place is of high stakeholder relevance in the case of a regional intervention (see also Vanclay, 2012). Most of the stakeholders in our case study were born and raised in the community and therefore had a strong sense of regional belonging and community cohesion. In addition, an obligation to their ancestors was also important. The people of East Friesland feel strongly connected to their traditions and history, something especially true in relation to flood protection measures. They are concerned that the land their ancestors reclaimed from the sea might be taken back again. Furthermore, the stakeholders feared that current flood protection structures would be endangered by new developments. Therefore, active participation in transparent decision-making was highly important to every stakeholder and seen as obligatory for further planning processes. For most of the stakeholders it was important that the planning of new land use management strategies had positive outcomes for all participants. Trust is one element of social well-being that has strong social effects. On the one hand, some stakeholders did not trust politicians because they feared the negative effects of policy-making. On the other hand, all of them thought highly of the regional water control boards.
Overall, the results of the interviews concerning constitutive development impacts suggest the need for adaptation measures concerning climate change (Table 2). Nevertheless, the stakeholders' opinions concerning climate change and possible adaptation measures differed. Almost all of the stakeholders were uncertain about the possible effects of climate change with regard to agricultural areas. Some considered that agricultural processes might suffer, while others thought that new developments might result and new species might immigrate. The stakeholders thus suggest that climate change both threatens and provides new opportunities for future land use management. The positioning of new land use measures and strategies was considered to play a significant role in alleviating any disruption to daily life caused by new developments. At present, there is already competition for land and the stakeholders expected that this would increase in the future. With respect to changing land use in the future, some stakeholders were concerned about resettlement and expropriation due to new developments. In addition, every stakeholder expressed a fear of losing land and opportunities. Compliance with property rights and values proved to be a factor which influences spatial decision-making and spatial development processes.

\section{Integration of social impacts and ecosystem services}

The combination of direct, indicative social impacts with ecosystem services is rather complex (Fig. 3 and Tables 2 and 3). Their relationship provides a set of causalities, dependencies and feedback loops: on the one hand, the indicative social impacts describe the feelings, expectations and needs of the community's demand for ecosystem services. Therefore, the provision of ecosystem 
services is directly influenced by the indicative social impacts. On the other hand, ecosystem services describe the supply of natural resources, in other words, the supply of services influences societal demand in turn the indicative social impacts.

Fig. 3 illustrates in detail that the indicative economic impacts described in Table 2 interact with provisioning ecosystem services (Table 3). The economic impact is related to the social impact in terms of economic activities, material well-being and the prosperity of the community (Vanclay, 2002), with provisioning services obtaining to the products people derive from ecosystems (MA, 2003). In this respect, the results suggest that following societal demands are of high relevance and enhance the material well-being of the people. This includes security of income, economic prosperity and the resilience of the region, the maintenance of agricultural and grassland areas as well as food security and drinking water supply. These demands are fulfilled by provisioning ecosystem services: food, forage and green energy production and fresh water retention, for drinking water extraction or agricultural use. Within the stakeholder dialogue, the provisioning ecosystem services build up a basis for the regional economy, especially characterized by the provision of products. The indicative economic impacts support the importance of the provisioning services which are strong supply directed needs.

The indicative climate change impacts refer to the stakeholders' conception of combating the negative effects of climate change, such as storm surges or river run off, as well as the perception of safety (Table 2). The interviews clarified that most of the stakeholders were not aware of regulating services provided by ecosystems for hazard regulation, such as water retention areas or wave attenuation (Table 3). For example, only a few stakeholders believed that retention areas were useful to relieve flooding (Table 3, white boxes), although the indicative climate change impacts were of high relevance (Table 2, grey boxes). The water management sector, in particular, emphasized that as long as the coastal protection continues as it is today, safety will be ensured. Additionally, stakeholders from all sectors, apart from nature conservation, argued in favour of the technical strengthening of the dikes with concrete, asphalt or sheet pile walls. By explaining regulating ecosystem services and their potential as alternative possibilities to current, mostly technical solutions, the stakeholder dialogue ascertained that stakeholders are now in a process of increasing awareness concerning the advantages and relevance of regulating services.

The results suggest that indicative landscape impacts (Table 2) are linked with cultural ecosystem services (Table 3). Cultural ecosystem services concern the non-material benefits that people obtain from ecosystems and are related to people's behaviour with regard to creating opportunities for recreation and cultural development (MA, 2003). Indicative landscape impacts are determined by the stakeholders' interests in and perceptions of the aesthetic quality of the landscape, its liveability and how people feel about their surroundings (Vanclay, 2002). Cultural services, such as community identification and connection as well as recreation and tourism based on the ecosystems, promote human well-being. In the stakeholders' opinion, the aesthetic and recreational value of the landscape was precious. The residents identified with the landscape, and it was thought that visible changes to it might lead to an 'alienation of the culture'. The stakeholders from the agricultural, political and tourism sectors emphasized that East Friesland is a human-made landscape and not 'natural'. In their opinion, the important elements of the landscape are the diversity of land uses, its pastoral, traditional and idyllic character, as well as the cultural-historical value of the terp villages (historical settlements built on artificial mounds up to $5 \mathrm{~m}$ above sea level in the case study region, which before dikes were built, served as flood protection measures), representing the typically East Frisian landscape. Both the presence of tourists and recreation opportunities are promoted by the landscape and the unique ecosystem. The community of Krummhörn depends on the presence of tourists (social impact) as an important sector of the economy, maintaining employment as well as income levels. In addition to these positive effects, some stakeholders mentioned that tourism also disrupted daily life and negatively influenced the landscape and environment. However, all stakeholders expected an increase in tourism in the coming years. The tourism sector works with ecosystem services associated with typical regional images such as grazing cows, the water and coastal areas and the structured and idyllic character of the community of Krummhörn. Due to changing land uses some stakeholders feared that the attractiveness of the landscape might decrease. It was considered very important to maintain the typical character of the region.

Supporting ecosystem services (Table 3) are underlying functions, such as biodiversity and soil quality, which are necessary for the production of all other ecosystem services (MA, 2003). The results suggest that these functions are associated with indicative ecological impacts (Table 2), relating to the stakeholders' feelings and aspirations about environmental issues, such as natural beauty, organic management and the sustainable use of natural resources. In addition, the impact of 'beauty of nature' is correlated with the service 'biodiversity'. In the stakeholders' opinion, the variety of species is crucial to natural beauty and its maintenance is highly relevant to the preservation of biodiversity. However, their aspirations and perceptions concerning nature protection differed slightly. The nature protection sector favoured an increasing, extensive use of grassland. Nature protection and conservation was also highly significant to the agricultural sector, which emphasized the connection between nature protection and agricultural use, such as production-integrated compensation measures or increasing organic and regional management.

Based on these results, the development of new sustainable land use management strategies can be promoted. The results make it clear that the stakeholders favoured multifunctional land use, combining different elements, to create mosaic structures and balancing the supply and demand of ecosystem services. The future development of the landscape in the region and the ongoing crosssectoral participation in decision-making were of special interest to the stakeholders. However, an essential aspect in spatial planning activities is an understanding of the stakeholders' perceptions, interests and needs, not least because stakeholders are responsible for the implementation of new planning strategies.

\section{Discussion}

Overall, the case study has shown that current and future land use management will likely face an increasing demand for resources provided by local ecosystems, while the possibilities of supply will be limited and decrease, partially due to changes in the landscape. Social demands and ecological supplies are not independent variables, but interact, and it is necessary to raise stakeholders' awareness of these linkages. The guideline presented in this paper delivers such an approach, required for adaptive spatial planning (Chan et al., 2012; de Groot et al., 2010; Esteves et al., 2012; Nahlik et al., 2012).

The proposed process schema for coastal land management was tested on the Krummhörn case, considering ecosystem services and social issues in a balanced and holistic manner. Involving stakeholders in data collection is useful (Fig. 2, grey background), as they are affected by interventions and, therefore, are able to identify problems and develop ideas and solutions, which in turn enhance the practicability and long-term viability of an intervention (see also Bryson, 2004; Eden and Ackermann, 1998; Freeman, 1984; Gregory and Keeny, 1994; Vanclay, 2012). In other words, 
they are considered to be experts who act as sectoral representatives of a specific field of action and, generally, have privileged access to information and take on specific responsibilities (see also Flick, 2006). Their involvement conforms with generic insights into and literature on stakeholders and stakeholder participation typical to sustainable regional development. Furthermore, stakeholder participation in planning activities is defined as a process in which stakeholders play an active role in determining the research objectives and their effectiveness throughout the entire research process (Bell et al., 2012; Reed, 2008; Schirmer, 2011). Chan et al. (2012), Díaz et al. (2011) and Nahlik et al. (2012) highlight the need for stakeholder integration and the development of interdisciplinary methodological approaches in order to understand mutual connections between natural and social subsystems. The guideline presented in this paper was applied in a regional governance process and revealed that stakeholder engagement, participation, involvement and dialogue is needed at every process phase (Fig. 2) to gain a holistic overview of possible development schemes (see also Baines et al., 2003). This finding reflects the general academic understanding of integrated water and coastal zone management, which argues for the incorporation of different layers of governance, participation, knowledge generation and stakeholder support to implement policies (Pickaver et al., 2010). As noted, this paper highlighted stakeholder participation through semi-structured interviews, making this the first phase of an ongoing participation process, as the research has also shown that the development of planning strategies is continuous and timeconsuming.

The results also reveal that stakeholder-driven actions offer a series of practical contributions to planning processes. They (i) help to identify development goals such as sustainable development and (ii) verify the positive outcomes and reduce the negative impacts of an intervention on people and the landscape. Furthermore, ongoing interactions with multiple stakeholders improve the identification of local ecosystem services and key social issues.

In order to develop a substantive communication process and support the development of sustainable land use management strategies it is important to make scientific language more understandable. For example, Pidgeon and Fischhoff (2011) highlight the crucial role of scientists in making the complex climate-related research understandable to policymakers and the public. The investigation illustrated that in land use management practice it is impossible, or at least very difficult, for some stakeholders or planning experts to work directly with ecosystem services. This is not because they have no interest in this approach and the related general considerations, but because of present they are not specifically trained in or familiar with the ecosystem services approach as a foundation for planning processes. The results demonstrate that the use of social categories and impacts leads to a better understanding (see also Vanclay and Esteves, 2011). The stakeholders tend to rely heavily on social units as their guiding framework. It is common for stakeholders to think in terms of social units because they identify with specific social impacts that are of relevance to them in relation to any action. The application of a social impact analysis within the sphere of planning presented here creates possibilities to integrate the ecosystem services approach into sustainable planning processes. In our case study, the stakeholder-driven process, in particular, contributed to an overall picture of the community affected and provided a broad background for categorizing important ecosystem services and social impacts (see also Esteves et al., 2012). The stakeholder dialogue raised awareness with regard to the need for adaptive strategies that would lead to sustainable development and human well-being in the community, as well as an understanding of what type of impact human interventions may have on natural systems.
This paper has substantiated this role for integrated coastal land use management through linking social impact analysis with the ecosystem services approach (Fig. 3). The guideline presented deals with various conceptions and perceptions, thereby attempting to express them as much as possible in a language speaking to the realities of the experts, and aiming for mutual understanding between researchers and stakeholders. Within the sphere of spatial planning, the investigation suggests that it should be obligatory to take constitutive impacts into account in the strategic development of planning activities. Consideration of the constitutive impacts is essential to all stakeholders, as they exert an influence on more than one category of ecosystem services and are relevant throughout the planning process, while indicative social impacts influence and depend on just one category of ecosystem services (Fig. 3).

The results suggest that science-driven actions are based on the strengths of the ecosystem services approach and social impact assessment (Fig. 2). Both concepts aim for ecologically, socioculturally and economically sustainable development that enhances human well-being (MA, 2003; Vanclay, 2003a). Within the guideline, the ecosystem services approach is used as a strategy to integrate the management and assessment of natural resources into complex human-environment systems (MA, 2003). Additionally, social impact assessment assists in the identification, analysis and evaluation of the social impacts of an intervention on a community and regional ecological structures. It provides a qualitative evaluation of the social impacts as a tool for decision-makers which can be used in planning processes, and which triggers adaptation measures (see also Burdge, 1999, 2003; Esteves et al., 2012; Vanclay, 2002; Vanclay, 2012).

In order to reduce complexity and organize the flow of information, one step in developing the guideline was the creation of categories of ecosystem services and social impacts (Fig. 3 and Tables 2 and 3). During the investigation it became obvious that including local, traditional and practitioner knowledge from stakeholders in strategy development generally improves the theoretical understanding of development in coastal areas. It may also assist the evaluation of the potential benefits and risks (see also Vanclay, 2003a). The results suggest the effectiveness of management processes is improved by using practitioner knowledge. Additionally, the use of local knowledge has been revealed as essential for the evaluation and identification of trade-offs and synergies concerning possible planning impacts. The distribution of stakeholder statements shown in Tables 2 and 3 demonstrates that different sectors have different requirements concerning the indicators and associated criteria. The crucial elements resulting from stakeholder involvement in planning activities include the better consideration, effectiveness and acceptance of an intervention within the community. This leads to participatory, informal and transparent decision-making processes, awareness-raising, trust-building and knowledge-sharing (Baines et al., 2003; Esteves et al., 2012; MA, 2003). These positive elements can be achieved through interactions between the theoretical and practical aspects presented in the guideline (Fig. 2).

The research reveals that stakeholders need to feel that their opinions will contribute to potential development processes and that they are actively involved. Another tool that might make possible changes more concrete is the creation of scenarios (Chan et al., 2012). Scenario planning supports decision-making with regard to uncertainty and integrates new strategies in order to justify possible consequences (Mietzner and Reger, 2005; Bishop et al., 2007).

The guideline presented here is based on the needs of informal planning practices, integrating the particular interests of the stakeholders. The analysis mainly considered the dependencies between ecosystem services and social impacts, and illustrated that the social impacts were more connected to such services than was generally thought. It is interesting to note that an even richer 
variety of interactions between social impacts and ecosystem services may actually occur. During the research process it became obvious, for example, that there may be both direct and indirect social impacts. In order to evaluate these kinds of linkages, social impacts must be dealt with in a more flexible manner, thereby discerning their relationships with various categories of services and uncovering their more indirect effects. For example, the fear of increasing drought or increasing inland water levels is associated with regulating services (direct), but could also affect food, forage or green energy production and therefore be related to provisioning services (indirect). Another example is the presence of tourists. With respect to cultural services, tourism may disrupt daily life and landscapes (direct). However, it is also necessary for the economic prosperity of the region and may be dependent on the implementation of new land use strategies and influenced by provisioning services (indirect). The extension of the guideline through the inclusion of direct and indirect impacts might be of interest in any further economic evaluation of possible planning measures.

The development of improved land use strategies for the various changing land use patterns is vital to minimize climate change impacts and increase adaptive capacity in a given region. Approaches coping with these challenges and several processes have provided first results recently. Projects aiming at adaptive spatial planning projects like Climate Proof Areas (2009) or ComCoast (Ahlhorn, 2009; Bormann et al., 2012) are dealing with consequences of climate change and suggest innovative adaptation strategies for the North Sea coastal regions. The dynamic and interdisciplinary process reflected in the guideline promotes sustainable land management strategies and is iterative. The reduction of uncertainty and the identification of how different stakeholders are affected by the interventions are also of central interest (see also Schirmer, 2011). Future research should address the benefits and weigh the surplus value of reduced or increased ecosystem services against the anticipated benefits or adverse effects of proposed developments. Monitoring and evaluation processes, as well as ex post studies, should also be included in the management process.

\section{Conclusion}

Adaptive strategies are the basis for sustainable land use management. Spatial planning processes aimed at the development of such sustainable strategies influence the structures of communities and ecosystems. For these reasons, the development of new land use management strategies requires a well-balanced framework which takes both social and ecological issues into account.

This paper developed a guideline which integrates both the social impacts of interventions and the ecosystem services affected by interventions into a participatory process. This planning and assessment guideline assists in understanding the interests and needs of the wider community and integrating stakeholders into the planning process. As we have seen, stakeholders' views and needs are crucial in developing a local planning framework through multi-step informal processes.

The advantages of an aggregation of the ecosystem services approach with social impact assessment are suggested to be related to the following points:

- The research process has made it obvious that the scientific background of the ecosystem services approach is often not easy to communicate. In addition, the stakeholder communication process is strongly connected to stakeholder perceptions and experiences. Stakeholders typically express their perceptions and needs in social terms. An understanding of the social impacts is necessary to help integrate the concept of ecosystem services into planning processes, allowing the translation of the various stakeholder perspectives into scientific discussions on ecosystem services.

- The guideline optimizes decision-making processes by applying qualitative research. As shown, this kind of research incorporates social demands into ecosystem-based research and thereby allows a better understanding of human well-being. In addition, it reduces the complexity of scientific language and helps to engage stakeholders.

The results reveal how both the ecosystem services approach and social impact assessment support stakeholder-driven adaptive land use planning and management. This finding is illustrated in Fig. 3 and with the help of Tables 2 and 3. An aggregation of both approaches tends to promote the integration of the ecosystem services approach into planning processes and delivers substantial contributions to the development of sustainable spatial planning projects. The results suggest that the social impacts can be used as a 'map' to assist the guidance of ecosystem services. These social impacts may be characterized by the demands of society, as expressed by the stakeholders involved. Additionally, interdependencies with respect to society (social impacts) may be examined in relation to their influence and the understanding of ecosystem services and future development schemes. Therefore, the integrated process discussed here is a step forward, away from conceptual frameworks, theories and more formal ways of practical integration (Daily and Matson, 2008) towards an informal and practical approach, thereby making planning and decision-making more effective (de Groot et al., 2010).

The case study revealed that an evaluation of causalities and characteristics that take stakeholders' opinions into account leads to an assessment of their interests, preferences and needs in relation to natural resources. This guideline is likely to provide an adequate basis for the development of action-oriented suggestions concerning spatial planning strategies. The concept of sustainable development was shown to be applicable when environmental and socioeconomic impacts are considered in an integrated way. Reflecting on the guideline, it is apparent that on the one hand research and knowledge about environmental and functional changes alone, for example climate change, cannot steer such processes. However, on the other hand, the consideration of social change processes without consideration of the impacts on or due to changes in ecosystems is also not adequate. Therefore, a transdisciplinary approach is necessary, addressing and incorporating the interdependency of nature and society and leading to a holistic understanding of change processes. Within the guideline, the borders of research have been exceeded and actionoriented suggestions for sustainable land use developed, enhancing the interactions between science and society through stakeholder engagement and decision support.

The guideline presented delivers a cross-sectoral, participatory approach promoting sustainable coastal land use planning that focuses on the supply and demand of resources. A crucial aspect is to initiate informal planning sessions aimed at the fulfilment of multiple demands by taking local and regional actors' knowledge and opinions into account. It is suggested that the participatory approach allows for the merging of the scientific concepts of the ecosystem services approach and social impact assessment. The interaction with stakeholders in the research process demonstrated that transparent and participative planning sessions are necessary to achieve sustainable land use management and to take into account the different ambitions and needs of the various sectors. During the research process, the stakeholders saw the additional value of the guideline, which assisted them to understand sustainable land management and influenced further actions. Additionally, the participative process also indicated that the willingness of stakeholders to adopt innovations in decision-making processes 
increases in accordance with their level of participation in the development process.

The proposed guideline deepens our understanding of the mutual dependencies and interactions between ecosystem services and their social impacts and promotes interdisciplinary, integrative research as well as the transfer of courses of action for decision-makers. The guideline offers a new basis on which to successfully make decisions and also promotes a collaborative and transparent planning process. By facilitating the incorporation of ecosystem services into the decision-making process, ecosystem services become projectable, while the impact assessment strengthens the ecosystem services approach by incorporating the demands of society. Clearly, the different interests of the stakeholders must to be brought together and when stakeholders with individual expertise work together they will be able to further enhance future projects. Thus, in cooperation with local stakeholders, it is possible to develop new sustainable land management strategies that take a holistic view.

The guideline uses social impact analysis as a bridging concept to make the ecosystem services approach more accessible, translating social impacts into ecosystem services. The guideline also helps explain possible land use changes arising from the sphere of planning in terms of social impacts. This operationalization of the ecosystem services approach and social impact analysis shows that social demands and the provision of ecosystem services are inherently connected.

\section{Acknowledgements}

The authors would like to thank the support of the fourteen regional experts who took part in this study, representing the five sectors of water management, nature conservation, agriculture, policy and tourism. Their many insights were invaluable in enabling and promoting our research.

\section{References}

Ahlhorn, F., 2009. Long-Term Perspective in Coastal Zone Development: Multifunctional Coastal Protection Zones. Springer-Verlag, Berlin, 220 pp.

Baines, J., McClintock, W., Taylor, N., Buckenham, B., 2003. Using local knowledge. In: Becker, H.A., Vanclay, F. (Eds.), The international Handbook of Social Impact Assessment - Conceptual and Methodological Advances. Edward Elgar Publishing Limited, Cheltenham, pp. 26-41.

Bell, S., Morse, S., Shah, R.A., 2012. Understanding stakeholder participation in research as part of sustainable development. J. Environ. Manage. 101, 13-22.

Beniston, M., Stephenson, D.B., Christensen, O.B., Ferro, C.A.T., Frei, C., Goyette, S., Halsnaes, K., Holt, T., Jylhä, K., Koffi, B., Palutikof, J., Schöll, R., Semmler, T., Woth, K., 2007. Future extreme events in European climate: an exploration of regional climate model projections. Clim. Change 81, 71-95.

Bishop, P., Hines, A., Collins, T., 2007. The current state of scenario development: an overview of techniques. Foresight 9, 5-25.

Bogner, A., Littig, B., Menz, W., 2009. Interviewing Experts - Research Methods. Palgrave Macmillan, New York, $281 \mathrm{pp}$.

Bormann, H., Ahlhorn, F., Klenke, T., 2012. Adaptation of water management to regional climate change in a coastal region - hydrological change vs. community perception and strategies. J. Hydrol. 454-455, 64-75.

Bryson, J.M., 2004. Strategic Planning for Public and Nonprofit Organizations: A Guide To Strengthening and Sustaining Organizational Achievement, 3rd ed. Jossey-Bass, San Francisco, 464 pp.

Burdge, R.J., 1999. A Community Guide to Social Impact Assessment, revised ed. Social Ecology Press, Middleton, $174 \mathrm{pp}$.

Burdge, R.J., 2003. The practice of social impact assessment - background. Impact Assess. Project Appraisal 21 (2), 84-88.

Carpenter, S.R., Mooney, H., Agard, J., Capistrano, D., DeFries, R.S., Díaz, S., Dietz, T., Duraiappah, A.K., Oteng-Yeboah, A., Pereira, H.M., Perrings, C., Reid, W.V., Sarukhan, J., Scholes, R.J., Whyte, A., 2009. Science for managing ecosystem services: beyond the Millennium Ecosystem Assessment. PNAS 196 (5), 1305-1312.

Chan, K.M.A., Guerry, A.D., Balvanera, P., Klain, S., Satterfield, T., Basurto, X., Bostrom, A., Chuenpagdee, R., Gould, R., Halpern, B.S., Hannahs, N., Levine, J., Norton, B., Ruckelshaus, M., Russell, R., Tam, J., Woodside, U., 2012. Where are cultural and social in ecosystem services? A framework for constructive engagement. Bioscience 62 (8), 744-756.

Climate Proof Areas, 2009. Time to adapt!. http://www.climateproofareas.com/ (accessed 27.02.12).
Constanza, R., D'Arge, R de Groot, R S., Farber S Grasso, M., Hannon, B., Limburg, K., Naeem, S., O’ Neill, R.V., Paruelo, J., Raskin, R.G., Sutton, P., van den Belt, M., 1997. The value of the world's ecosystem services and natural capital. Nature 387, 253-260.

Daily, G.C., Matson, P.A., 2008. Ecosystem services: from theory to implementation. PNAS 105 (28), 9455-9456.

de Groot, R.S., Alkemade, R., Braat, L., Hein, L., Willemen, L., 2010. Challenges in integrating the concept of ecosystem services and values in landscape planning, management and decision making. Ecol. Complex. 7, 260-272.

de Groot, R.S., Wilson, M., Boumans, R., 2002. A typology for the description, classification, and valuation of ecosystem functions, goods and services. Ecol. Econ. 41 (3), 393-408.

Díaz, S., Quétiera, F., Cáceresb, D.M., Trainor, S.F., Pérez-Harguindeguy, N., BretHarte, M.S., Finegan, B., Pena-Claros, M., Poorter, L., 2011. Linking functional diversity and social actor strategies in a framework for interdisciplinary analysis of nature's benefits to society. PNAS 108 (3), 895-902.

Eden, C., Ackermann, F., 1998. Making Strategy: The Journey of Strategic Management. Sage Publications, London, 509 pp.

Esteves, A.M., Franks, S. Vanclay, F., 2012. Social impact assessment: the state of the art. Impact Assess. Project Appraisal 30 (1), 35-44.

European Union, 2012. Confronting Scarcity: managing water, energy and land for inclusive and sustainable growth. Belgium, $208 \mathrm{pp}$.

Fish, R., Burgess, J., Church, A., Turner, K., 2011. Shared values for the contributions ecosystem services make to human well-being. In: UK National Ecosystem Assessment (Ed.), The UK National Ecosystem Assessment Technical Report. UNEP-WCMC, Cambridge, pp. 1183-1193.

Fisher, B., Turner, R.K., Morling, P., 2009. Defining and classifying ecosystem services for decision making. Ecol. Econ. 68, 643-653.

Flannery, W., Cinnéide, M., 2011. Stakeholder participation in marine spatial planning: lessons from the Channel Islands National Marine Sanctuary. Soc. Nat. Resour. 25, 727-742.

Flick, U., 2006. An Introduction to Qualitative Research, 3rd ed. Sage Publications Ltd., London, 448 pp.

Freeman, R.E., 1984. Strategic Management: A Stakeholder Approach. Pitman, Boston, $276 \mathrm{pp}$

Grabemann, I., Weisse, R., 2008. Climate change impact on extreme wave conditions in the North Sea: an ensemble study. Ocean Dyn. 58 (3-4), 199-212.

Gregory, R., Keeny, R.L., 1994. Creating policy alternatives using stakeholder values. Manage. Sci. 40 (8), 1035-1048.

Interorganizational Committee on Guidelines and Principles for Social Impact Assessment (Ed.), 1995. Guidelines and Principles for Social Impact Assessment. Institute for Environmental Studies. Environ. Impact Assess. Rev. 15 (1), 1-43.

Katsman, C.A., Sterl, A., Beersma, J.J., Hazeleger, W., van den Brink, H.W., Church, J.A., Kopp, R.E., Oppenheimer, M., Kroon, D., Kwadijk, J., Lammersen, R., Lowe, J., Ridley, J., Plag, H.-P., von Storch, H., Weisse, R., Vaughan, D.G., Vellinga, P., Vermeersen, L.L.A., van de Wal, R.S.W., 2011. Exploring high-end scenarios for local sea level rise to develop flood protection strategies for a low-lying delta the Netherlands as an example. Clim. Change 9, 617-645.

Jacob, D., Göttel, H., Kotlarski, S., Lorenz, P., Sieck, K., 2008. Klimaauswirkungen und Anpassung in Deutschland - Phase 1: Erstellung regionaler Klimaszenarien für Deutschland. Umweltforschungsamt des Bundesministerium für Umwelt, Naturschutz und Reaktorsicherheit: Forschungsbericht 20441138 UBA-FB 000969.

LGLN, 2012. Landesamt für Geoinformation und Landentwicklung Niedersachsen. In: Auszug aus den Geobasisdaten der Niedersächsischen Vermessungs-und Katasterverwaltung. www.lgln.niedersachsen.de

M.A. - Millennium Ecosystem Assessment (Ed.), 2003. Ecosystems and Human WellBeing. A Framework for Assessment. Island Press, Washington, $245 \mathrm{pp}$.

Mietzner, D., Reger, G., 2005. Advantages and disadvantages of scenario approaches of strategic foresight. Int. J. Technol. Intell. Plan. 1 (2), 220-239.

Nahlik, A.M., Kentula, M.E., Fennessy, M.S., Landers, D.H., 2012. Where is the consensus? A proposed foundation for moving ecosystem service concepts into practice. Ecol. Econ. 77, 27-35.

Neef, A., Neubert, D., 2001. Stakeholder participation in agricultural research projects: a conceptual framework for reflection and decision-making. Agric. Hum. Values 28, 179-194.

Nicholls, R.J., Wong, P.P., Burkett, V.R., Codignotto, J.O., Hay, J.E., McLean, R.F., Ragoonaden, S., Woodroffe, C.C., 2007. Coastal systems and low-lying areas. In: Parry, M.L., Canziani, O.F., Palutikof, J.P., van der Linden, P.J., Hanson, C.E. (Eds.), Climate Change 2007: Impacts, Adaptation and Vulnerability. Contribution of Working Group II to the Fourth Assessment Report of the Intergovernmental Panel on Climate Change. Cambridge University Press, Cambridge, pp. 315-356.

Österblom, H., Gardmark, A., Bergström, C., Müller-Karulis, B., Folke, C., Lindegren, M., Casini, M., Olsson, P., Diekmann, R., Blenckner, T., Humborg, C., Möllmann, C., 2010. Making the ecosystem approach operational - can regime shifts in ecological- and governance systems facilitate the transition? Mar. Policy 34, 1290-1299.

Pickaver, A., Steijn, R., Ferreira, M., Czerniak, P., Devilee, E. (Eds.), 2010. Ourcoast: Integrated Coastal Zone Management - Participation Practices in Europe. Publication Office of the European Union, Luxemburg, $36 \mathrm{pp}$.

Pidgeon, N., Fischhoff, B., 2011. The role of social and decision sciences in communicating uncertain climate risks. Nat. Clim. Change 1 (1), 35-41.

Polasky, S., Carpenter, S.R., Folke, C., Keeler, B., 2011. Decision-making under great uncertainty: environmental management in an era of global change. Trends Ecol. Evol. 26 (8), 398-404. 
Reed, M.S. 2008. Stakeholder participation for environmental management: a literature review. Biol. Cons. 141, 2417-2431.

Salter, J., Robinson, J., Wiek, A., 2010. Participatory methods of integrated assessment - a review. Wiley Interdiscip. Rev. Clim. Change 1 (5), 697-717.

Schirmer, J., 2011. Land use change. In: Vanclay, F., Esteves, A.M. (Eds.), New Directions in Social Impact Assessment: Conceptual and Methodological Advances. Edward Elgar, Cheltenham, pp. 171-185.

Slootweg, R., Vanclay, F., van Schooten, M., 2001. Function evaluation as a framework for the integration of social and environmental impact assessment. Impact Assess. Project Appraisal 19 (1), 19-28.

Spekat, A., Enke, W., Kreienkamp, F., 2007. Neuentwicklung von regional hoch aufgelösten Wetterlagen für Deutschland und Bereitstellung regionale Klimaszenarios auf der Basis von globalen Klimasimulationen mit dem Regionalisierungsmodell WETTREG auf der Basis von globalen Klimasimulationen mit ECHAM5/MPI-OM T63L31 2010 bis 2100 für die SRESSzenarios B1, A1B und A2. Forschungsprojekt im Auftrag des Umweltbundesamtes FuE-Vorhaben: Förderkennzeichen 20441 138, 149 pp.

UK National Ecosystem Assessment, 2011. The UK National Ecosystem Assessment: Synthesis of the Key Findings. UNEP-WCMC, Cambridge, $87 \mathrm{pp}$.
Vanclay, F., 2002. Conceptualising social impacts. Environ. Impact Assess. Rev. 22 183-211.

Vanclay, F., 2003a. International principles for social impact assessment. Impact Assess. Project Appraisal 21 (1), 5-11.

Vanclay, F., 2003b. Conceptual and methodological advances in social impact assessment. In: Becker, H.A., Vanclay, F. (Eds.), The International Handbook of Social Impact Assessment - Conceptual and Methodological Advances. Edward Elgar Publishing Limited, Cheltenham, pp. 1-9.

Vanclay, F., 2012. The potential application of social impact assessment in integrated coastal zone management. Ocean \& Coastal Management 68, 149-156.

Vanclay, F., Esteves, A.M., 2011. Current issues and trends in social impact assessment. In: Vanclay, F., Esteves, A.M. (Eds.), New Directions in Social Impact Assessment: Conceptual and Methodological Advances. Edward Elgar, Cheltenham, pp. 3-19.

Wallace, K.J., 2007. Classification of ecosystem services: problems and solutions. Biol. Conserv. 139, 235-246.

Woth, K., Weisse, R., von Storch, H., 2005. Climate change and North Sea storm surge extremes: an ensemble study of storm surge extremes expected in a changed climate projected by four different Regional Climate Models. Ocean Dyn. 56, 3-15. 